\title{
Is Transition Experience Enough? The Donor-side Effectiveness of Czech and Polish Democracy Aid to Georgia
}

\author{
Balázs Szent-Iványi ${ }^{\mathrm{a}, \mathrm{b}}{ }^{*}$ and Zsuzsanna Végh ${ }^{\mathrm{c}}$ \\ a Aston Centre for Europe, Aston University, Aston Triangle, Birmingham B4 7ET, UK \\ ${ }^{b}$ Institute of World Economy, Corvinus University Budapest, Fövám tér 8, Budapest, 1093, Hungary \\ ${ }^{c}$ Comparative Politics Chair, European University Viadrina, Große Scharrnstrasse 59, 15230 Frankfurt (Oder), \\ Germany
}

\begin{abstract}
The paper examines the democracy aid practices of the Czech Republic and Poland in Georgia. These two countries have recently emerged as promoters of democracy, and have argued that their own transition experience puts them in a unique position to support democratization and the consolidation of democracy in the EU's Eastern Neighbourhood. The paper evaluates how these two countries provide democracy aid to Georgia along three criteria, derived from the aid effectiveness literature: supporting locally driven change, learning from results and coordination. The results indicate that both countries have plenty of space to improve the way their democracy aid is delivered. Neither country has formal systems in place to ensure that they actually support Georgian priorities; evaluations are ad hoc and feedback loops missing; and there is significant scope to improve coordination with other donors. Nonetheless, there seems to be a general perception among stakeholders that the democracy aid provided by the Czech Republic and Poland is relevant to Georgia’s needs.
\end{abstract}

Keywords: Georgia, Poland, Czech Republic, foreign aid, democracy aid

* Corresponding author. Email: b.szent-ivanyi@aston.ac.uk

Acknowledgement: the authors are grateful to Anna-Sophie Maass, Paul Cardwell, Marek Neuman, and two anonymous referees for comments on earlier versions, as well as participants at the 'The Crisis of Democracy Promotion' workshop at the University of Groningen, 10-11 March 2016. Any remaining errors however are ours. 


\section{Introduction}

The Central and Eastern European (CEE) member states of the European Union (EU) have emerged in the past decade as increasingly vocal democracy promoters, building on their own experience in transition from Communist rule to democracy. They have made democracy assistance an important component of their bilateral international development policies, and have been actively seeking to influence the way the EU and other international organisations support democratization and democratic consolidation, ${ }^{1}$ especially in the EU's neighbourhood. Official rhetoric in the CEE countries argues that due to their own experience with, and strong belief in the transformative power of democracy, they can be highly effective when supporting democratization in their partner countries.

There is now a sizeable literature analysing the democracy promotion policies and practices of the CEE countries, including their bilateral democracy aid, their political engagement with democratizing countries, and their impact on the policies of international organisations. ${ }^{2}$ While we now know much about the motivations behind CEE democracy aid, the various forms it takes and how it is delivered, we still know relatively little about the interactions between these new promoters of democracy and their partner countries, and how they seek to make these more effective through planning, coordination and better implementation.

This paper contributes to filling this gap by examining the democracy aid of the Czech Republic and Poland to Georgia. The aim of the paper is to determine the degree to which the implementation of the two CEE countries' democracy aid in Georgia meets the criteria for effective democracy assistance on the donors' side. If these countries truly perceive themselves as effective donors due to their transition experience, then they should be interested in maximizing the benefits of their democracy aid by actually using effective practices.

The Czech Republic and Poland have been identified in the literature as the most active and consistent promoters of democracy from the CEE region, ${ }^{3}$ and have had long lasting relations with Georgia. Georgia is an ideal partner to examine how these CEE countries provide and implement democracy assistance, as in the aftermath of the 2003 Rose Revolution Georgia proved to be one of the more committed reformers in the post-Soviet region. After the Georgian-Russian war in 2008, and the launch of the EU's Eastern Partnership initiative, much advocated by the CEE countries, ${ }^{4}$ the relative importance of Georgia increased even further.

The paper evaluates the democracy aid practices of the two donors in Georgia against three criteria derived from the literatures on the effectiveness of foreign and democracy aid: support for locally driven change, learning from results and coordination. The empirical material is

\footnotetext{
${ }^{1}$ See the contributions in Berti et al. eds, Democratization in EU Foreign Policy.

${ }^{2}$ See for example Petrova, From Solidarity to Geopolitics; Pospieszna, Democracy Assistance from the Third Wave; Szent-Iványi and Lightfoot "Central and Eastern European Transition Experience.”

${ }^{3}$ Petrova, From Solidarity to Geopolitics.

${ }^{4}$ Dangerfield, “The Contribution of the Visegrad Group to the European Union’s ‘Eastern’ Policy.”
} 
based on the analysis of the two countries' democracy aid practices as reported through official documents, as well as 16 qualitative interviews carried out in 2015 with the two countries' diplomats in Tbilisi and their respective capitals, Georgian officials in the Ministry of Foreign Affairs (MFA) and the Office for European and Euro-Atlantic Integration, as well as Czech and Polish NGOs working in Georgia and Georgian NGOs who have worked with partners from the two donor countries. To ensure confidentiality, respondents remain anonymous.

The main finding of the paper is that despite their rhetoric on being effective, the Czech Republic and Poland have made few conscious efforts to ensure that their democracy aid meets basic requirements of effectiveness, such as the three fundamental criteria used by this paper. These criteria are mirrored in the international aid effectiveness agenda (including the Paris Declaration of 2005 and the 2011 Busan Partnership), which both donors have endorsed, thus it is not unrealistic to expect them to implement these principles in their aid practice. Given the centrality of the 'transition narrative' justifying the comparative advantage of their democracy aid, the lack of attention to effectiveness calls into question just how seriously these claims should be taken. Nevertheless, the content of their assistance, based on their transition experience, is still seen by partners as highly relevant to the Georgian context. These findings show that CEE democracy aid, at least in the case of the two donors examined, has added value in the Eastern neighbourhood, however, more conscious efforts are needed to improve effectiveness on the donor side.

Two notes are in order on what the paper does not aim to do. First, it focuses only on democracy assistance, defined as a part of foreign aid, either in the form of funding or technical assistance, which has the goal of strengthening democratic institutions, democratic governance by state institutions, or civil society capacities to monitor the state and foster civic engagement. It does not discuss political engagement and human rights advocacy directed at the Georgian government, nor does it focus on the political support that the two donors give Georgia in international organisations such as the EU or NATO. Second, the paper does not aim to carry out a full, formal evaluation of Czech and Polish democracy aid in Georgia. The three effectiveness criteria used in the paper focus on the supply side of democracy aid, and they thus represent those determinants of effectiveness over which donors have a significant degree of control. If the two countries wanted to improve the effectiveness of their democracy aid, the supply side would be the place to start. The ultimate impact of Czech and Polish democracy aid, i.e. greater levels of democracy in Georgia, is beyond their control, and depends on multiple factors, including Georgian political dynamics and geopolitics, which the donors have little or no influence on. Indeed, Schmitter ${ }^{5}$ has argued that democratization needs to be driven internally, and domestic limitations, as well as windows of opportunity ${ }^{6}$ are key to understanding change, or the lack of it. This of course does not mean that external interventions such as democracy aid cannot help in the process, especially if done well.

\footnotetext{
${ }^{5}$ Schmitter, "The Influence of the International Context upon the Choice of National Institutions and Policies in New Democracies.”

${ }^{6}$ Brückner and Ciccone, "Rain and the Democratic Window of Opportunity.”
} 
The remainder of the paper is structured as follows. After a review of the literature on democracy aid with a view of consolidating what it sees as effective practice, some descriptive details of the democracy aid practices of the Czech Republic and Poland are discussed. This is followed by the application of the insights from the aid literature to analyse the effectiveness of the practices of the two countries in Georgia. The final section offers some concluding remarks.

\section{When is the supply of democracy aid effective?}

Using foreign aid to promote regime change and democratic consolidation is a relatively new phenomenon. Aid has traditionally focused on promoting economic development, and democracy was seen as something that will emerge once the right structural conditions are in place. ${ }^{7}$ After the early 1990s however, donors increasingly saw the creation of well functioning democratic institutions as a prerequisite for development. ${ }^{8}$ This shift was driven by a number of factors, including the end of the Cold War and the supposed triumph of liberal democracy; the continuation of the fourth wave of democracy; new generation of peace and state building interventions; a general aid fatigue; and new arguments put forward by the academic literature, mainly new institutionalist political economy. ${ }^{9}$ Many donors thus began using parts of their foreign aid budgets to promote democratic change. While the democracy aid practices of the United States have received much attention, the EU created a dedicated aid instrument to support democratization, the European Instrument for Democracy and Human Rights in 1994, and bilateral donors also began introducing democratization programmes. $^{10}$

Democracy aid, just like foreign aid in general, involves a transfer of resources or expertise between a donor and a recipient. Thus, the literature on the effectiveness of foreign aid can be a good starting point for deriving criteria to assess the effectiveness of democracy aid. This literature generally agrees that aid can be effective in promoting development and reducing poverty, but only under certain circumstances. ${ }^{11}$ These circumstances refer to either conditions in the recipient country, or to how donors give aid. Recipient country characteristics relate to well functioning institutions, effective state bureaucracies, low levels of corruption, and some degree of democracy. ${ }^{12}$ On the donor side, many (seemingly technical) fixes have been identified which can improve aid effectiveness, including greater coordination and harmonisation between donors, alignment with recipient country priorities and ensuring recipient ownership, untying aid from exports, using recipient country systems,

\footnotetext{
${ }^{7}$ De Zeeuw, “Projects do not create institutions”, 482.

${ }^{8}$ Przeworski et al. "Democracy and Development”, Grimm and Leininger, "Not all good things go together”.

${ }^{9}$ Acemoglu et al., “The Colonial Origins of Comparative Development”.

${ }^{10}$ Wright, “How Foreign Aid Can Foster Democratization in Authoritarian Regimes.”

${ }^{11}$ Doucouliagos and Paldam, “Conditional Aid Effectiveness.”

12 Kosack, "Effective Aid”; Burnside and Dollar, “Aid, Policies and Growth: Revisiting the Evidence”; Wright,

"Aid Effectiveness and the Politics of Personalism”.
} 
increasing accountability, better evaluation and learning from results. ${ }^{13}$ These donor-side problems are mirrored well in the international aid effectiveness agenda, especially in documents like the Paris Declaration (2005) or the Busan Partnership (2011).

However, democracy aid is also distinct from foreign aid, making it unclear just how much the recommendations for effective foreign aid are valid for the case of democracy aid. Democracy aid does not directly aim to support development, although developmental approaches to democracy assistance do not ignore it either, ${ }^{14}$ but to promote a transition to democracy or support the consolidation of new(er) democratic regimes. It also takes different forms: while foreign aid projects are associated with visible and directly measurable outputs like roads or hospitals, democracy aid focuses on supporting democratic institutions and procedures, the reform of democratic governance by state institutions or civil society and the media. ${ }^{15}$ Instead of large scale financial transfers to the recipient state, democracy aid generally involves technical assistance (expert advice, training workshops, study visits etc.), or direct financing to support the activities of various non-state actors.

Unlike the Paris Declaration or the Busan Partnership, no internationally adopted document has laid down guidelines on how to increase the effectiveness of democracy support. This can be explained by the fact that evaluating the effectiveness of democracy aid is particularly challenging. In terms of methodological problems, Burnell highlights the difficulty of defining and measuring the dependent variable, democratic progress; establishing causal linkages between outputs (e.g. the number of CSOs trained) and impacts (democratic progress), or between the input of a particular donor and the general progress of the recipient country, which is influenced by multiple factors; or even establishing a realistic timeframe in which to expect results. ${ }^{16}$ Additionally, carrying out the evaluations also poses political and logistic challenges, raising questions about the motivations behind the evaluation, the potential for bias, the frequent lack of financial and human resources or the pressure to search for low-hanging fruits to validate success. ${ }^{17}$

Even if these challenges were to be addressed, the variety of (country) cases and the complexity of democratization processes would still render it difficult to identify generalizable good practices. The ignorance of the context and the failure to develop a suitable, well thought-through strategy can easily hamper effectiveness: in different political contexts democracy aid needs to have different goals and should target those through different

\footnotetext{
${ }^{13}$ Knack and Rahman, “Donor Fragmentation and Bureaucratic Quality in Aid Recipients”; Riddel, “Does Foreign Aid Work?”; Guljarani, “Organising for Donor Effectiveness”; Bingsten and Tengstam, “International Coordination and the Effectiveness of Aid.”

${ }^{14}$ Carothers, “Democracy Assistance: Political vs. Developmental?”

${ }^{15}$ Carothers, “Democracy Aid at 25.”

${ }^{16}$ Burnell, “Does International Democracy Promotion Work?”

${ }^{17}$ Green and Kohl, “Challenges of Evaluating Democracy Assistance.”
} 
means, identifying the appropriate stakeholders for cooperation, the suitable time to use various instruments or the sequencing of support measures. ${ }^{18}$

Democracy aid does not operate in a vacuum and is faced with conflicting objectives, which often go unaddressed by the donors. The lack of strategic considerations concerning these conflicts (e.g. between promoting democracy and/or stability) can impact the effectiveness of democracy assistance negatively. ${ }^{19}$ The situation is similarly problematic when the donor's goals are ill-defined. ${ }^{20}$

Indeed, due to the nature of democracy aid, it is primarily the donors' responsibility to develop practices and find the context-specific means that can improve effectiveness. ${ }^{21}$ Although overarching good practices are hard to draw due to the reasons mentioned above, some lessons have emerged over the course of the past decades. Carothers has identified a set of such lessons, ${ }^{22}$ which could be regarded as baseline criteria for donor-side effectiveness, although they are not sufficient guarantees for success. These include the need to develop a good understanding of the contexts donors operate in, which requires a presence in the given country and analytical capacities devoted to making sense of developments. Ready-made solutions offered by the donors can be harmful, and they should rather focus on identifying and supporting locally generated change. Donors should support rooted and legitimate NGOs, as opposed to often detached elite advocacy groups and should ensure CSOs strengthen their domestic constituencies. ${ }^{23}$ Despite the difficulties, donors need to follow up, evaluate and learn from their activities. Finally, cooperation with other democracy supporters as well as partnership with donors of development aid can also contribute to increasing the effectiveness of democracy aid.

Democracy aid, like development aid, often involves technical assistance, thus insights from the literature on development aid might hold some lessons for democracy aid, too. Technical assistance is usually seen as highly donor-driven and not necessarily aligned with the needs of the recipients. ${ }^{24}$ Donors may have experience in certain areas, which they are keen to transfer, but this may not be what the recipient needs most. Many donors have been accused of exporting Western models, which do not work in recipient contexts. Indeed, the Busan Partnership emphasizes the importance of partners setting their own development priorities. ${ }^{25}$

\footnotetext{
${ }^{18}$ Gräwingholt et al., “The Three Cs of Democracy Promotion Policy.”

${ }^{19}$ Grimm and Leininger, "Not All Good Things Go Together."

${ }^{20}$ Wetzel and Orbie, “Promoting Embedded Democracy?”

${ }^{21}$ Burnell, “Does International Democracy Promotion Work?”

${ }^{22}$ Carothers, “Democracy Aid at 25.”

${ }^{23}$ See also Fagan, “Taking Stock of Civil-Society Development in Post-communist Europe.”

${ }^{24}$ Godfrey et al., “Technical Assistance and Capacity Development in an Aid-dependent Economy.”

${ }^{25}$ Busan Partnership for Effective Development Cooperation, 11.
} 
Most of the funds spent on technical assistance often "end up in the bank accounts of consultants from high-income countries."26

Based on this overview of the literature on foreign and democracy aid effectiveness, the paper's analytical framework proposes three cumulative but foundational criteria for assessing the supply side of Czech and Polish democracy aid: supporting locally driven change, learning from results, and coordination. This framework incorporates a significant portion of the aid effectiveness conditions discussed by the literature, yet it keeps the analysis concise and manageable by streamlining those. Additionally, these three criteria focus on the supply side effectiveness of democracy aid, that is the frameworks and procedure on the donor side, without getting entangled in assessing the actual impact of democracy aid.

Support for locally driven change is a compound criterion to assess to what degree the donor takes into account the local context, including, (1) if and how it seeks alignment with the reform priorities identified by state recipients; (2) if and how it addresses the needs of nonstate actors, by, for example, engaging with bottom-up, locally driven initiatives; and (3) whether the donor has the ability and capacities to analyse the local context and tailor its assistance accordingly, which includes the ability to strike the right balance between state and non-state actors..$^{27}$ Support for locally driven change, as Carothers also suggests, is not guided by the donor's models and priorities, but emphasizes the need for a clear sense of ownership on the recipient's side and alignment to local needs, ${ }^{28}$ be they defined by the state or by non-state actors. When working with state actors, well aligned democracy aid considers the priorities set by the (ideally reform-minded), government, but should reflect on their intentions and credibility as well. Working with non-state actors requires reaching out to and empowering embedded local stakeholders who can provide local solutions. These can be achieved through mechanisms of close consultations during the planning and programming phases of democracy aid, or by granting recipient actors, including state actors and CSOs, wide possibilities in identifying how to spend the assistance. Finding the balance that can improve the effectiveness of democracy aid is heavily dependent on the donor's capacities to analyze the local context, and channel this analysis into policy.

The second criterion, learning from results, focuses on whether the donors make efforts to learn from their practices and their impact in the local contexts of the given recipients. Keeping in mind that democratic change can take a long time, donor commitment and the improvement of the donor's practice are crucial. Aid agencies thus need to learn from their experiences, and improve their practice based on lessons from the field. ${ }^{29}$ Regular independent evaluations can provide such insights and can also make donors more accountable, especially if their results are published. Donors also need to put organizational

\footnotetext{
${ }^{26}$ Easterly and Pfutze, "Where Does the Money Go?”, 33.

${ }^{27}$ Gräwingholt, et al. especially emphasize the importance of context sensitivity and the need for a strategy for long-term systemic support.

${ }^{28}$ Carothers, "Democracy Aid at 25”. Leininger and Ziaja, “Conflicting Objectives in Democracy Promotion” put much emphasis on avoiding the imposition of donors ideas, or as they call it, the "blueprint trap".

${ }^{29}$ Green and Kohl, “Challenges of Evaluating Democracy Assistance.”
} 
mechanisms and procedures into place (e.g. regular policy reviews), which build on these evaluations to create a feedback loop in order to improve the effectiveness of democracy aid by adjusting the donors' practice over time. ${ }^{30}$

Finally, the criterion of coordination refers to how donor agencies responsible for democracy aid work with others. This has two aspects: (1) an intra-donor aspect, i.e. how well democracy aid is coordinated with development or even humanitarian aid from the same donor; ${ }^{31}$ and (2) an inter-donor aspect referring to the way the donor coordinates its democracy aid with other donors. Improving inter-donor coordination can be achieved in several ways, representing different intensities of coordination. On the lowest level, donors can meet regularly to exchange information on their activities in the given country, while more advanced coordination can mean joint programming, funding or implementation. ${ }^{32}$

Before applying these three criteria to Czech and Polish democracy aid practices in Georgia, the following section provides a brief review of the emergence of CEE countries as donors of democracy aid.

\section{The CEE countries as democracy promoters}

The Czech Republic started its international development policy in 1995, followed by Poland and other CEE countries after the turn of the Millennium. This process, as well as the subsequent evolution of these policies has been well documented in the literature. ${ }^{33}$ Most CEE countries chose to emphasise their recent experiences gained through transition to democracy, market economy, and integration in the EU as an added value to their approach to international development cooperation, and many of them have made the promotion of democracy an integral part of these activities. ${ }^{34}$ They choose most of their partner countries from the Western Balkans and the EU's Eastern neighbourhood, as many of these countries were still engaged in similar transformation processes, making them logical recipients of the type of democracy aid these donors sought to offer.

The CEE states see themselves as having a special added value in democracy aid projects in transition countries, due to the experience they have amassed during their own transition processes. ${ }^{35}$ According to this 'transition narrative', ${ }^{36}$ their transition puts them into a unique

\footnotetext{
${ }^{30}$ Busan Partnership for Effective Development Cooperation, 12.

${ }^{31}$ See also Grimm and Leininger, "Not All Good Things Go Together.”

32 Busan Partnership for Effective Development Cooperation, 25.

${ }^{33}$ See Szent-Iványi and Lightfoot, New Europe's New Development Aid.

${ }^{34}$ This is of course not to say that democracy promotion based on transition experience is the only international development priority these two countries have. Both countries align, at least in their written strategies, to the general priorities of development voiced by the EU or the OECD, including poverty reduction and sustainable development (see Szent-Iványi and Lightfoot, New Europe's New Development Aid).

${ }^{35}$ Kucharczyk and Lovitt, Democracy's New Champions.

${ }^{36}$ Szent-Iványi and Lightfoot, “Central and Eastern European Transition Experience.”
} 
position to effectively support democratic change and consolidation in partner countries who harbour similar goals. This narrative allows the CEE countries to portray themselves as different in comparison to 'traditional' donors, who may have more resources, but lack firsthand experience with transition, which often renders their assistance irrelevant. ${ }^{37}$ The CEE countries, on the other hand, portray themselves as able to provide highly relevant assistance, which is well aligned with local contexts and national reform needs, and thus can be more effective in stimulating progress towards the desired outcome, greater democracy.

Reflecting this understanding, support for democracy is listed among the priorities of most CEE countries' official development assistance, and many of them have created dedicated organisational structures, in addition to their structures focusing on development and humanitarian assistance, to promote it. In the Czech Republic, the 'Act on Development Cooperation and Humanitarian Aid and Amending Related Laws' lists the promotion of democracy, human rights and good governance among the priorities of Czech development assistance, and the development cooperation strategy for 2010-2017 lists democracy promotion and human rights as a sectoral priority. A separate department responsible for transition promotion and human rights was set up in the MFA to run the country's Transition Promotion Program (TPP), aimed at supporting democratic transition in partner countries. In Poland, the multiannual development cooperation program for 2012-2015 lists democracy and human rights as a cross-cutting thematic area supported by Polish development assistance and refers to Poland's credentials by enlisting its post-1989 transition experience. Furthermore, the country created the Solidarity Fund, a foundation aiming to support 'democracy in countries undergoing political transformation, by offering assistance in bringing about democratic changes to societies which cannot, under the incumbent regimes, co-decide their fate, and by supporting observance of human rights worldwide'. ${ }^{38}$

While some contributions in the literature have been rather upbeat about the potential of the CEE countries to contribute effectively to democratization in their partner countries, ${ }^{39}$ others have questioned just how well the transition narrative performs in practice. Horký, ${ }^{40}$ as well as Szent-Iványi and Lightfoot ${ }^{41}$ have both questioned just how much transition experience can be seen as a comparative advantage in democracy promotion, and whether it is not more than a self-legitimising discourse. It is difficult however to draw any clear conclusions, as there have been few formal, impartial, and methodologically sound impact assessments of CEE democracy aid activities to date.

When it comes to evaluating how serious the CEE countries are beyond their rhetoric about providing democracy aid, a look at the share of democracy aid in their development aid disbursements shows that financially they cannot be seen as 'democracy promotion "heavy

\footnotetext{
${ }^{37}$ Poszpieszna, “When Recipients Become Donors.”

${ }^{38}$ See the Fund's website at http://solidarityfund.pl/en/.

${ }^{39}$ See for example Poszpieszna, "When Recipients Become Donors.”

${ }^{40}$ Horký, “The Transfer of the Central and Eastern European 'Transition Experience’ to the South.”

${ }^{41}$ Szent-Iványi and Lightfoot, “Central and Eastern European Transition Experience.”
} 
hitters",. ${ }^{42}$ While they spend a relatively larger share of their foreign aid on democracy aid than more established donors (see Table 1), these are still small amounts due to their very limited aid budgets. For example, the Czech Republic and Poland spent a total of 7 and 19.2 million dollars respectively in 2015 on supporting 'government and civil society' in their partner countries (OECD 2017). ${ }^{43}$ These amounts are further fragmented into a multitude of tiny projects, mostly implemented by NGOs and public administration organisations based in the donor country, and generally take the form of technical assistance.

\section{$<$ TABLE $1>$}

Although the absolute amounts of democracy aid are small, their effectiveness still matters. If these countries want to live up to their rhetoric on being more effective promoters of democracy in transition countries, they need to make efforts to develop effective supply-side frameworks, procedures and practices. The following section investigates to what extent the Czech Republic and Poland have managed to develop these in the context of Georgia.

\section{Czech and Polish democracy aid to Georgia Descriptive details}

Both countries have engaged in supporting development and democratic consolidation in Georgia after the 2003 Rose Revolution, when the pro-Western, government of Mikheil Saakashvili came into power, ${ }^{44}$ but it was after the Georgian-Russian war in 2008 that their development relations became significant. The Czech Republic tripled its assistance in 2008 compared to 2007, and Poland almost doubled it. 2009 was a peak year for Czech and Polish assistance, and annual aid flows have since then remained substantially higher than in 2007 (see Table 2), which can signify continued commitment from the donors' side.

\section{$<$ TABLE $2>$}

Table 2 reveals that approximately a third of the Czech assistance to Georgia can be classified as democracy aid. Data for Poland only exist after 2013, and show a slightly lower ratio. Details for individual projects funded by the two countries are incomplete, but both the Czech and Polish embassies have published brochures which give some degree of overview of their

\footnotetext{
${ }^{42}$ Petrova, The New Role of Central and Eastern Europe in International Democracy Support, 18.

${ }^{43}$ Based on data from the OECD's Creditor Reporting System. Aid spent on 'Government and civil society' is the best available proxy for democracy aid, given that neither the Czech Republic, nor Poland publishes statistics on the exact amounts of their democracy aid.

${ }^{44}$ For more about the Rose Revolution, see Jones, “The Rose Revolution.”
} 
activities. Based on these and annual reports, it is possible to identify some of the main areas of democracy aid and the types of projects that are implemented by the two donors in Georgia.

Czech democracy aid after 2008 was allocated through two channels: the development assistance policy of the country, but more importantly the TPP. Based on projects reported by the Czech Development Agency (CzDA) ${ }^{45}$ the former concentrated predominantly on public administration reform and capacity building in various sectors, while the latter focused mainly on the local level, including NGOs and local authorities. The goal was to strengthen NGOs' involvement in decision-making and improve their relations with local authorities. With regards to local authorities, Czech aid supported public finance management trainings to foster transparency and develop their capacities.

A focus area of Polish democracy support has also been local administration development, and in 2008-2010 Poland was allegedly the biggest donor focusing on this area. In 2011, the Solidarity Fund launched extensive cooperation with NGOs to strengthen civil society and citizens' participation in the political life of Georgia. In 2012, Poland started to provide courses for Georgian officials on management of public finances, security and defence policy; and by starting the Strategic Economic Needs and Security Exercise (SENSE), on the principles of a functioning market economy. ${ }^{46}$

\section{Supporting locally driven change}

Democracy aid is more effective when donors make efforts to align it with the needs and priorities of the recipient, including state and non-state actors, and whether they have the analytical capabilities to determine how exactly to work with these actors. On the state level, Georgia's reform priorities have mainly been formulated, together with the EU, by generally reform-minded governments, and thus can be considered to reflect a more genuine wish for the country's democratization. The EU's ENP Action Plan, signed with Georgia in 2006, outlined the reforms Georgia should implement under the Partnership and Cooperation Agreement (PCA) that provided the framework for EU-Georgia relations since 1999. These reforms were accepted by Georgia as well: 'The ENP Action Plan is largely consistent with Georgia's vision,' and reflects the priority areas for reform emphasised by the Prime Minister in Parliament in February 2005. The government accepted a Medium-Term Action Strategy for 2007-10, which aimed to implement the actions listed in the ENP Action Plan. The first priority area in the Action Plan clearly related to strengthening democratic governance. ${ }^{47}$

Subsequently, Georgia signed an Association Agreement (AA) with the EU in June 2014, including a Deep and Comprehensive Free Trade Area (DCFTA). Implementing these requires serious political, economic and trade-related reform along with wide-ranging

\footnotetext{
${ }^{45}$ Embassy of the Czech Republic, The Czech Development and Transition Projects.

${ }^{46}$ Polish Aid, Georgia; Embassy of Poland in Georgia, Georgian-Polish Development Co-Operation 2008-2010.

${ }^{47}$ European Commission, EU/Georgia Action Plan, 4.
} 
alignment with the EU acquis. The AA also put a strong emphasis on political reform, listed under the section of 'political dialogue and reform'. Georgian interviewees, both from CSOs and the state administration, when asked about the priorities of the country where external support is needed, mainly pointed towards the implementation of both the AA and the DCFTA, thus endorsing the reform agenda set for Georgia jointly with the EU. ${ }^{48}$

To what extent do Czech and Polish democracy aid seek to take these into account? Simply put, the processes through which their democracy aid, and indeed other aid, are planned towards Georgia do not ensure alignment at all. The following statement by an interviewee implies that very little discussion with the Georgian officials goes into planning the assistance:

We have contacts with the [Georgian] ministries, but it is mainly our ambassador informing them of what we are doing. We do not ask the ministries what we should do, and we don't make policy together. Lobbying the government is left to the big donors. $^{49}$

In fact, neither country has developed clear strategic approaches, (publically available) documents, or any specific frameworks for Georgia which would reflect in-depth considerations for a country-specific strategy, and which could, in turn, serve as a reference point for their democracy promotion activities. The Czech Republic has strategies for its 'program countries', but Georgia is classified as a 'project country'. While Poland classifies Georgia as a priority partner country, it does not publish strategy papers. Thus, without written strategies, the aid provided to Georgia remains ad hoc to some degree, and it is also much more difficult to identify the steps that have been taken to ensure alignment with the Georgian context. The lack of strategies may signify that neither country devotes the necessary analytical capacities to making sense of the Georgian situation.

The ad hoc nature of assistance is strengthened by the practice that both donor countries implement the bulk of their democracy aid through open calls for proposals and on a projectbasis, which hampers overarching planning and purposeful alignment, and explains that the partner is only informed ex-post. ${ }^{50}$ While this bottom-up logic could be beneficial to channel local stakeholder interests (which in turn could make assistance to Georgia aligned with locally driven change even if clear strategies are missing), room for Georgian initiatives is rather limited. Proposals for projects need to be submitted to the MFAs generally by Czech/Polish NGOs or government agencies. Involving a Georgian partner in the proposal is required in the Czech Republic, but not in Poland, although a Polish interviewee has stated that proposals involving local partners have higher chances of success. ${ }^{51}$ An exception is the Czech Republic's funding for human rights and transition projects, which is only accessible for Georgian NGOs, but it is restricted to tiny projects (usually below $€ 5,000$ ). Additionally,

\footnotetext{
${ }^{48}$ Interviews \#03, \#04, \#05, \#16.

${ }^{49}$ Interview\#01.

${ }^{50}$ Interview\#06.

${ }^{51}$ Interview\#07.
} 
Czech and Polish government agencies also have funds - usually outside the formal development assistance frameworks and managed without MFA involvement - for cooperation with their Georgian counterparts. The fact that both donors encourage the participation of Georgian NGOs can be seen as a tool to ensure some degree of sensitivity to supporting locally driven change, but it is ultimately still Czech or Polish NGOs and government agencies which initiate the projects. ${ }^{52}$

Despite these problems inherent in the way Czech and Polish democracy aid is delivered, almost all interviewees, both from the donor side and, more importantly, the Georgian governmental and NGO sides have argued that the democracy assistance of the two donors is very relevant to the Georgian context. While this may seem paradoxical, a Georgian government official argued that while there are problems of coordination between the CEE countries and the Georgian government, these countries understand the needs of Georgia better than other donors, and have experience in similar reforms which are needed to implement the DCFTA in Georgia. ${ }^{53}$ Thus, even without explicit mechanisms to ensure that democracy aid answers to local needs, Czech and Polish aid is generally considered relevant. Representatives of Georgian NGOs have all supported this point, and argued that beyond the transition experience, the international networks to which CEE NGOs open Georgian NGOs up to through joint projects are often much more valuable than the support itself. These networks constitute important sources of learning much needed for Georgian NGOs, including on techniques of monitoring the government and engaging in better advocacy work.

Czech and Polish government officials can of course be biased and may be reluctant to admit potential problems about the relevance of their assistance. The responses of Georgian NGOs who receive funding from these two governments can also be biased to a certain degree. However, there is reason to believe that this was not the case: many of the Georgian NGO respondents were actually very critical on other aspects of Czech and Polish democracy aid, including their relatively small amounts and the attached bureaucratic burdens. To further control for potential biases in interviews, the available datasets of Czech and Polish projects in Georgia were also examined. ${ }^{54}$ Most of these, implemented by donor NGOs, show a good degree of alignment with Georgian priorities. A clear recurring theme among these projects is increasing participation in local decision-making, campaigning for more transparent public administration, and involving young people in political processes. Polish government entities, including municipalities, have also provided aid to their Georgian counterparts in terms of increasing transparency and openness towards their citizens. These projects resonate well with the broad priorities in the AA on strengthening democratic institutions and respect for human rights. An independent evaluation of Czech democracy support to Georgia between 2008 and

\footnotetext{
52 Interview\#07.

53 Interview\#03.

${ }^{54}$ Embassy of Poland in Georgia, Georgian-Polish Development Co-Operation 2008-2010; Embassy of the Czech Republic, The Czech Development and Transition Projects.
} 
2013, commissioned by the MFA, also found the overall relevance of Czech assistance to be 'rather high'. ${ }^{5}$

Nevertheless, all this seems to be rather by chance than design, given that there is little strategic analysis behind the donor's decisions, and no formal ex-ante engagement with the government. Working with locally embedded non-state actors could also be improved by giving them stronger opportunities to initiate projects, especially in the case of Poland.

\section{Learning from results}

CEE aid agencies generally do not perform well in terms of evaluating their practice and following up on these evaluations. ${ }^{56}$ It is argued that evaluations are often seen as criticism of government activities, and thus CEE governments resist it. ${ }^{57}$ While the Czech Republic has been carrying out evaluations of its development policy since 2003, the earliest available evaluations are from 2012. No evaluation reports are available for Poland before 2012 either. This means that development evaluation is a relatively new phenomenon among these countries, and even if the practice is now present, it is rather isolated: the individual evaluations generally focus on a few projects implemented in a given partner country in a specific sector. Whole-of-country or cross-sectoral evaluations are rare. The focus of the evaluations typically changes each year, and is defined by the MFAs and their interests at a given time. Furthermore, they certainly do not cover the entirety of the donor countries' development and democracy aid.

In the Czech Republic, ex-post evaluations are carried out by external evaluators who are generally experts in the field. The evaluations usually group together several projects that have been implemented in a specific partner country in the same field. The results of the evaluations are made public through the MFA's website, with at least their summaries translated to English. Evaluations are partly based on the monitoring conducted by the embassies and by the CzDA, but also go beyond this data. The earliest available evaluation about projects specifically in Georgia is from 2012, and the latest was published in 2016. The scope of the projects evaluated include health care (in 2013), agriculture (in 2012, 2015, 2016), which were indeed two key areas of Czech development support in Georgia, and there is also a comprehensive, but not all encompassing, evaluation of several democracy and human rights assistance projects implemented as part of the TPP between 2008 and 2013, published in 2014. ${ }^{58}$ This evaluation provided mixed results, and argued that while the evaluated projects did manage to engage local actors, they were less successful in promoting

\footnotetext{
${ }^{55}$ Ministry of Foreign Affairs of the Czech Republic, Report from the Complex Evaluation of the Czech Development Assistance.

${ }^{56}$ Szent-Iványi and Lightfoot, New Europe’s New Development Aid.

${ }^{57}$ Mora and Antonie, "Levers Supporting Program Evaluation Culture and Capacity in Romanian Public Administration.”

${ }^{58}$ Ministry of Foreign Affairs of the Czech Republic, Report from the Complex Evaluation of the Czech Development Assistance.
} 
long term change. The report also formulated recommendations on how Czech democracy aid to Georgia could be improved, including focusing on larger and longer-term projects, coordinating activities with other donors, as well as better planning.

In the case of Poland, the selection of projects for evaluation is based on the decision of the MFA, and can concern (groups of) projects or annual programs including activities financed and/or implemented by the MFA and the Solidarity Fund. Polish development activities implemented in Georgia have been evaluated multiple times, but only a part of them can be categorised as democracy aid, such as the SENSE training program, and projects addressing institutional reform in social care implemented in 2010-2011 (evaluated in 2012), support for SMEs in Georgia facilitating economic transformation (evaluated in 2014), and finally, democracy assistance projects sponsored by the Solidarity Fund (evaluated in 2015 alongside projects implemented in Tunisia and Ukraine). ${ }^{59}$ The evaluations were carried out by independent contractors and the evaluations provided practical recommendations to the MFA, the Polish Embassy in Georgia and project originators respectively. In certain cases, e.g. the SENSE program, the evaluation formulated clear suggestions for Poland's next multi-annual planning period as well.

Although the system of evaluations is still relatively new in both Poland and the Czech Republic, some lessons can be drawn based on their practice. As previously mentioned, neither country has detailed and bilaterally agreed country strategies with Georgia. In the absence of these, the relevance, effectiveness, impact and sustainability of certain projects can be studied, but can only be benchmarked either against the goals and objectives of the given project, or a broader and thus vaguer set of priorities outlined in higher level multiannual strategies. The evaluation cannot compare results to goals specifically tailored for, and with Georgia. Furthermore, the evaluations have neither been extensive, nor systematic to date. They have only covered a small part of these donors' democracy aid activities in Georgia, thus only limited feedback could have been channelled into subsequent project cycles. Indeed, based on interviews, feedback and learning loops seem to be missing. ${ }^{60}$ While evaluations of Czech and Polish democracy aid to Georgia both mention specific recommendations, there are no mechanisms in place in either country to ensure that these are channelled into future project planning. Staff at the Czech and Polish embassies in Tbilisi had no clear examples of evaluations leading to changes in their practice. ${ }^{61}$ A diplomat from one of the countries argued that the MFA probably has no clear opinion on the impact of democracy aid projects, despite existing evaluation. ${ }^{62}$

\section{Coordination}

\footnotetext{
${ }^{59}$ Polish Aid, Evaluation; Ecorys, Evaluation of selected initiatives under the Polish development cooperation programme.

${ }^{60}$ Interview\#02, interview\#08.

${ }^{61}$ Intevriew\#01, interview\#02.

62 Interview\#08.
} 
Intra-donor coordination is generally an issue in donor countries which have highly fragmented institutional set-ups for aid delivery. ${ }^{63}$ The two countries significantly differ on this, with the Czech Republic having a rather centralised system with the MFA and the CzDA at its centre, while in Poland the MFA plays a relatively weak coordinating role, and all lineministries have some degree of international development activity. As discussed above, both countries have created separate mechanisms for democracy aid, mainly with the goal of providing their democracy aid (and transition experience) greater visibility, but which at the same time exacerbate coordination issues.

In the Czech Republic, democracy aid in the framework of the TPP is run by a separate department (Human Rights and Transition) in the MFA than development, and the CzDA is less involved in these projects. On the other hand, many projects supported by the CzDA also have clear democracy promotion elements. While the two MFA departments and the CzDA are said to work closely, their calls for proposals are not synchronised. ${ }^{64}$ The evaluation report of Czech democracy aid to Georgia ${ }^{65}$ also stressed the need for greater coordination between the Human Rights and Transition department and the CzDA, in terms of programming, planning and monitoring. In the Polish case, an important coordination problem is raised by the fact that the democracy aid activities of individual government entities, including central and local government, do not go through the MFA. The budget for these activities is decentralised, and the MFA is often only ex-post informed about what is going on. The evaluation of the Solidarity Fund activities revealed the insufficiency of intra-donor cooperation among the MFA, the Fund and the Polish Embassy in Georgia. ${ }^{66}$

In terms of coordinating among donors, the mechanism in Georgia is operated by the European Commission's Delegation, which involves regular meetings of the development councillors from the EU member states' embassies. The main priority of the Commission is to get the member states on board in terms of supporting the reforms outlined in the AA, but some states, especially the bigger ones, have agendas of their own. ${ }^{67}$ The EC has no legal power to ensure that the member states take each other's actions into consideration, thus coordination meetings are at times little more than talking shops where each donor provides an update of their ongoing and planned activities. Among the CEE countries present in Georgia, the Czech Republic was seen as the most active in this forum, which can most likely be ascribed to the personality of its development diplomat. The evaluation report mentioned above however draws attention to the fact that the Czech Republic's democracy aid in Georgia would greatly benefit from engaging in 'joint programming, co-funding, monitoring and evaluation especially with the EC delegation, [...] and potentially also with other donors'.

\footnotetext{
${ }^{63}$ Szent-Iványi and Lightfoot, New Europe’s New Development Aid, Chapter 2; Grimm and Leininger, “Not all good things go together”.

64 Interview\#09.

${ }^{65}$ Ministry of Foreign Affairs of the Czech Republic, Report from the Complex Evaluation of the Czech Development Assistance, 4.

66 Ibid.

${ }^{67}$ Interview\#10.
} 
At the same time, Poland has been perceived as less active in EC-led donor coordination. ${ }^{68}$ The abovementioned evaluations provide a modest picture, too. The review of Polish aid for SMEs showed that no conflict occurred in the implementation of project activities with other donors and suggested that the supported projects filled a niche in Georgia. However, there is no indication that Poland would have sought cooperation with other donors to identify potential synergies either.

CEE interviewees themselves were surprisingly silent about their own inter-donor coordination efforts. One interviewed diplomat simply stated: 'Ask the European Commission, they are responsible for coordination, not us. ${ }^{69}$ Another stated that they coordinate their activities by ex-post informing the relevant Georgian government officials, on the assumption that they will then use this information to coordinate the work of other donors. $^{70}$ Georgian officials interviewed however argued that there are examples of duplications among projects funded by the two countries, and that they should step up their coordination efforts. ${ }^{71}$ The government formulates an annual action plan on the implementation of AA reforms, and these plans could serve as starting points for coordination. It is unclear however to what degree the donors, CEE and other, make use of this, and whether the Georgian government would have the capacities to lead coordination.

Based on these results, there clearly seems to be little emphasis in the case of the two donors on coordination with other democracy aid providers, and they also face internal coordination problems.

\section{Conclusions}

This paper has explored the democracy aid activities of the Czech Republic and Poland in Georgia. The two countries have argued that their transition experience allows them to be more effective donors of democracy aid, especially in the post-Soviet region. But in order for these claims to be credible, the donors have to put efforts into ensuring the supply-side effectiveness of their democracy aid. Building on the literature on aid effectiveness, the paper outlined three key criteria for effective democracy aid - support for locally driven change, learning from results, and coordination - and mapped the performance of the Czech Republic and Poland in Georgia along these.

The results of the analysis are summed up in Table 3, which leads to mixed conclusions: clearly, the two countries could do more to enhance the effectiveness of their democracy aid. Overall, their democracy aid based on transition experience seems to have some degree of alignment with Georgian priorities, but the processes through which Czech and Polish democracy aid are delivered lack strategic planning and any direct coordination with the

\footnotetext{
${ }^{68}$ Interview\#10.

${ }^{69}$ Interview\#11.

${ }^{70}$ Interview\#12.

${ }^{71}$ Interviews \#03 and \#04.
} 
Georgian government. Their focus on supporting and empowering local actors and initiatives is also limited, leaving much room for improvement. The two countries have already carried out some evaluations of their democracy, governance and human rights support in Georgia, and these evaluations generally meet the standards of such activities. There is nonetheless little explicit evidence of feedback loops and learning from results, without which the exercise does not complete its purpose.

$<$ TABLE $3>$

Coordination is perhaps the weakest of the three criteria discussed in this paper. Both countries struggle with intra-donor coordination problems, and neither of them seem keen to advance inter-donor coordination efforts. To improve intra-donor coordination, donors will need to reform their development and democracy assistance systems, and move away from ex-post coordination towards more strategic planning involving key stakeholders. Increasing the potential for inter-donor coordination is largely dependent on the reform of intra-donor coordination: if the representatives on the ground are only ex-post aware of their own countries' democracy support activities, it is impossible to increase the substance and effectiveness of inter-donor coordination.

As interviews suggest, Czech and Polish narratives, positioning themselves as democracy promoters, have been received with interest among Georgian stakeholders, and they find the knowledge these donors can share relevant. However, there is much to be improved. The findings of the paper identify several ways through which the two donors can improve their democracy assistance policies to increase effectiveness in the post-Soviet region. These findings are also relevant for the broader democratization literature. While democratization and democratic consolidation depend on a number of factors, many of which are beyond the control of democracy aid donors, donors can do much by improving their own practice. Nonetheless, in order to determine what the most common shortcomings are in the practice of donors and identify conclusions that are generalizable beyond the Czech/Polish-Georgian context and applicable to other donor-recipient contexts as well, more research is still needed.

\section{References}

Acemoglu, D., S. Johnson, and J.A. Robinson. "The Colonial Origins of Comparative Development: An Empirical Investigation.” American Economic Review 91, no. 5 (2001): 1369-1401.

Bergman, A. "Co-Constitution of Domestic and International Welfare Obligations. The Case of Sweden's Social Democratically Inspired Internationalism.” Cooperation and Conflict 41, no. 1 (2007): 73-99.

Berti, B., K. Mikulova and N. Popescu (eds). Democratization in EU Foreign Policy. New Member States as Drivers of Democracy Promotion. London: Routledge, 2016. 
Bingsten, A. and S. Tengstam. "International Coordination and the Effectiveness of Aid." World Development 69 (2015): 75-85.

Brückner, M. and Ciccone, A. "Rain and the Democratic Window of Opportunity.” Econometrica 79, no.3 (2011): 923-947.

Burnell, P. “Does International Democracy Promotion Work?” DIE Discussion Paper $17 / 2007$.

Burnside, C. and D. Dollar. “Aid, Policies and Growth: Revisiting the Evidence.” World Bank Policy Research Working Paper 3251(2004).

Carothers, T. “Democracy Aid at 25: Time to Choose.” Journal of Democracy 26, no. 1 (2015): 59-73.

Carothers, T. “Democracy Assistance: Political vs. Developmental?” Journal of Democracy 20, no.1 (2009): 5-19.

Dangerfield, M. “The Contribution of the Visegrad Group to the European Union's 'Eastern' Policy: Rhetoric or Reality?” Europe-Asia Studies 61, no. 10 (2009): 1735-1755.

Doucouliagos, H. and M. Paldam. “Conditional Aid Effectiveness: A Meta-Study.” Journal of International Development 22, no. 4 (2010): 391-410.

Easterly, W. and T. Pfutze. "Where Does the Money Go? Best and Worst Practices in Foreign Aid.” The Journal of Economic Perspectives 22, no. 2. (2008): 29-52.

Ecorys, Evaluation of selected initiatives under the Polish development cooperation programme implemented through the Ministry of Foreign Affairs of Poland in 20122014, including selected activities of the Solidarity Fund. Warsaw: MFA, 2015.

Embassy of Poland in Georgia. Georgian-Polish Development Co-Operation 2008-2010. Tbilisi, 2010.

Embassy of the Czech Republic. The Czech Development and Transition Projects. Tbilisi, 2012

European Commission. EU/Georgia Action Plan. Brussels, 2006.

Fagan, A. "Taking Stock of Civil-Society Development in Post-communist Europe: Evidence from the Czech Republic.” Democratization 12, no. 4 (2005): 528-547.

Godfrey, M., C. Sophal, T. Kato, L. Vou Piseth, P. Dorina, T. Saravy, T. Savora, S. Sovannarith. "Technical Assistance and Capacity Development in an Aid-dependent Economy. The Experience of Cambodia.” World Development 30, no. 3 (2002): 355-373.

Gräwingholt, J., J. Leininger and O. Schlumberger. "The Three Cs of Democracy Promotion Policy: Context, Consistency and Credibility.” DIE Briefing Paper 1/2009.

Green, A.T. and R.D. Kohl. "Challenges of Evaluating Democracy Assistance: Perspectives from the Donor Side.” Democratization 14, no. 1. (2007): 151-165. 
Grimm, S. and J. Leininger. "Not All Good Things Go Together: Conflicting Objectives in Democracy Promotion.” Democratization 19, no. 3. (2012): 391-414.

Gulrajani, N. "Organising for Donor Effectiveness: An Analytical Framework for Improving Aid Effectiveness.” Development Policy Review 32, no. 1 (2014): 89-112.

Horký, O. “The Transfer of the Central and Eastern European 'Transition Experience' to the South: Myth or Reality?” Perspectives on European Politics and Society 13, no. 1 (2012): 17-32.

Jones, S.F. “The Rose Revolution: A Revolution without Revolutionaries?” Cambridge Review of International Affairs 19, no. 1 (2006): 33-48.

Knack, S. and A. Rahman. "Donor Fragmentation and Bureaucratic Quality in Aid Recipients.” Journal of Development Economics 83, no. 1 (2007): 176-97.

Kosack, S. "Effective Aid: How Democracy Allows Development Aid to Improve the Quality of Life.” World Development 31, no. 1 (2003): 1-22.

Kucharczyk, J. and J. Lovitt (eds). Democracy's New Champions. European democracy assistance after EU enlargement. Prague: Pasos, 2008.

Leininger J. and S. Ziaja. "Conflicting Objectives in Democracy Promotion: Avoiding Blueprint Traps and Incomplete Democratic Transitions.” DIE Briefing Paper 11/2014.

Ministry of Foreign Affairs of the Czech Republic. Report from the Complex Evaluation of the Czech Development Assistance Supporting Human Rights, Democracy and Societal Transformation in Georgia, 2014. Accessed 30 March 2016. http://www.mzv.cz/file/1327329/EvalRep_Georgia2014_EN_final.pdf.

Mora, C. and R. Antonie. "Levers Supporting Program Evaluation Culture and Capacity in Romanian Public Administration.” Society and Economy in Central and Eastern Europe 34, no. 3 (2012): 423-432.

OECD. Creditor Reporting System, 2015. Accessed 30 March 2016. https://stats.oecd.org/Index.aspx?DataSetCode=CRS1.

Petrova, T. The New Role of Central and Eastern Europe in International Democracy Support. Washington D. C.: Carnegie Endowment for International Peace, 2011.

Petrova, T. From Solidarity to Geopolitics: Support for Democracy among Postcommunist States. Cambridge: Cambridge University Press, 2014.

Polish Aid. Georgia, 2014. Accessed 30 March 2016. https://www.polskapomoc.gov.pl/Georgia,188.html.

Polish Aid. Evaluation, 2016. Accessed 30 March 2016. https://polskapomoc.gov.pl/Evaluation,2033.html.

Pospieszna, P. "When Recipients Become Donors. Polish Democracy Assistance in Belarus and Ukraine.” Problems of Post-Communism 57, no. 4 (2010): 3-15. 
Pospieszna, P. Democracy Assistance from the Third Wave: Polish Engagement in Belarus and Ukraine. Pittsburgh: University of Pittsburgh Press, 2014.

Przeworski, A., M.E. Alvarez, J.A. Cheibub, F. Limongi. Democracy and Development. Cambridge University Press, 2000.

Riddel, R.C. “Does Foreign Aid Work?” In Doing Good or Doing Better. Development Policies in a Globalizing World, edited by M. Kremer, P. van Lieshout and R. Went, 47-80. Amsterdam: Amsterdam University Press, 2009.

Schmitter, P. “The Influence of the International Context upon the Choice of National Institutions and Policies in New Democracies”, The International Dimensions of Democratization, edited by L. Whitehead . Oxford: Oxford University Press, 1996.

Szent-Iványi, B. and S. Lightfoot, S. New Europe's New Development Aid. Abingdon: Routledge, 2015.

Szent-Iványi, B. and S. Lightfoot. "Central and Eastern European Transition Experience: A Depoliticisation of Democracy Aid?” In Democratization in EU Foreign Policy. New Member States as Drivers of Democracy Promotion, edited by B. Berti, K. Mikulova and N. Popescu. Abingdon: Routledge, 2016.

Wetzel, A. and J. Orbie. "Promoting Embedded Democracy? Researching the Substance of EU Democracy Promotion.” European Foreign Affairs Review 16 (2011): 565-588.

Wright, J. "How Foreign Aid Can Foster Democratization in Authoritarian Regimes.” American Journal of Political Science 53, no. 3 (2009), 552-571.

Wright, J. “Aid Effectiveness and the Politics of Personalism.” Comparative Political Studies 43, no. 6 (2010): 735-762.

de Zeeuw, J. "Projects do not Create Institutions: The Record of Democracy Assistance in Post-Conflict Societies.” Democratization 12, no. 4 (2005): 481-504.

\section{Interviews}

Interview\#01: Czech diplomat, Tbilisi, 03/08/2015.

Interview\#02: Polish diplomat, Tbilisi, 28/07/2015

Interview\#03: Georgian official, MFA, European Affairs Department, 07/07/2015.

Interview\#04: Georgian official, Office for European and Euro-Atlantic Integration, 10/07/2015.

Interview\#05: Georgian official, MFA, European Affairs Department, 03/08/2015.

Interview\#06: CzDA official, 04/05/2014

Interview\#07: Polish diplomat, Tbilisi, 23/07/2015 
Interview\#08: Czech diplomat, Prague, 23/07/2015

Interview\#09: Czech NGO expert, Tbilisi, 07/08/2015

Interview\#10: European Commission Delegation to Georgia official, 01/10/2015.

Interview\#11: Polish diplomat, Warsaw, 09/08/2015.

Interview\#12: Czech diplomat, Prague, 28/07/2015.

Interview\#13: Expert from a Georgian NGO which has received Czech funding, 18/08/2015.

Interview\#14: Polish NGO expert, Warsaw, 07/09/2015.

Interview\#15, Expert from a Georgian NGO which has received CEE funding, 03/09/2015.

Interview\#16, Expert from a Georgian NGO which has received Polish funding, 18/08/2015.

\section{Tables}

Table 1. Democracy aid of selected donors (annual averages for 2013-2015)

\begin{tabular}{|c|c|c|c|c|c|}
\hline Donor & $\begin{array}{l}\text { Democracy aid } \\
\text { (million USD) }\end{array}$ & $\begin{array}{l}\text { Share of total } \\
\text { aid budget (\%) }\end{array}$ & Donor & $\begin{array}{l}\text { Democracy aid } \\
\text { (million USD) }\end{array}$ & $\begin{array}{l}\text { Share of total } \\
\text { aid budget (\%) }\end{array}$ \\
\hline Austria & 36.0 & 4.7 & Slovakia & 4.2 & 23.3 \\
\hline Czech Republic & 8.5 & 12.4 & Slovenia & 4.2 & 17.5 \\
\hline Denmark & 133.5 & 6.3 & Spain & 116.8 & 13.2 \\
\hline France & 179.4 & 1.9 & Sweden & 911.2 & 20.5 \\
\hline Germany & $1,832.3$ & 10.4 & $\overline{\mathrm{UK}}$ & 870.0 & 10.5 \\
\hline Japan & 485.5 & 2.5 & USA & $4,188.6$ & 14.5 \\
\hline Poland & 20.4 & 15.3 & $\begin{array}{l}\text { OECD DAC } \\
\text { average }\end{array}$ & 432.2 & 10.8 \\
\hline
\end{tabular}

Source: authors, based on data from OECD (2017).

Note: democracy aid is proxied by 'government and civil society’ aid. 
Table 2. Total aid and democracy aid to Georgia from the Czech Republic and Poland, 2008-

2015

\begin{tabular}{|c|c|c|c|c|c|c|c|c|c|}
\hline & & 2008 & 2009 & 2010 & 2011 & 2012 & 2013 & 2014 & 2015 \\
\hline \multirow{2}{*}{$\begin{array}{l}\text { Czech } \\
\text { Republic }\end{array}$} & Total aid & 2.10 & 5.28 & 3.76 & 1.84 & 2.57 & 2.84 & 2.88 & 3.29 \\
\hline & Democracy aid & .. & .. & .. & 0.49 & 0.87 & 0.98 & 1.01 & 1.04 \\
\hline \multirow{2}{*}{ Poland } & Total aid & 2.53 & 12.01 & 6.3 & 6.38 & 2.68 & 3.47 & 2.54 & 2.37 \\
\hline & Democracy aid & .. & .. & .. & .. & .. & 1.16 & 0.74 & 0.58 \\
\hline
\end{tabular}

Source: OECD (2017).

In million dollars, 2014 prices and exchange rates.

Table 3. Supply side effectiveness of Czech and Polish democracy aid to Georgia

\begin{tabular}{|c|c|c|}
\hline & Czech Republic & Poland \\
\hline $\begin{array}{l}\text { Support for } \\
\text { locally driven } \\
\text { change }\end{array}$ & $\begin{array}{l}\text { - No formal processes to ensure } \\
\text { alignment to national priorities and } \\
\text { identification of locally embedded } \\
\text { stakeholders } \\
\text { - Small grants fund available for local } \\
\text { NGOs; involvement of Georgian } \\
\text { partner required for projects } \\
\text { - Assistance is perceived as relevant for } \\
\text { local needs }\end{array}$ & 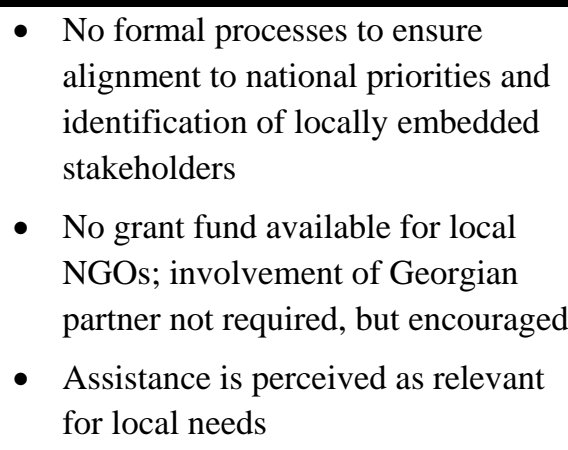 \\
\hline $\begin{array}{l}\text { Learning from } \\
\text { results }\end{array}$ & $\begin{array}{l}\text { - } \text { Ad hoc evaluations } \\
\text { - } \quad \text { Relatively transparent } \\
\text { - } \quad \text { No feedback loops }\end{array}$ & $\begin{array}{l}\text { - } \text { Ad hoc evaluations } \\
\text { - } \quad \text { Less transparent } \\
\text { - } \quad \text { No feedback loops }\end{array}$ \\
\hline Coordination & 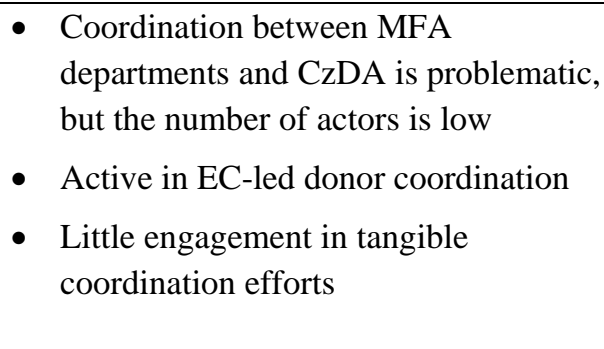 & $\begin{array}{l}\text { - The multitude of actors and the } \\
\text { weakness of the MFA makes intra- } \\
\text { donor coordination difficult } \\
\text { - Less active in EC-led donor } \\
\text { coordination } \\
\text { - Little engagement in tangible } \\
\text { coordination efforts }\end{array}$ \\
\hline
\end{tabular}

Source: authors 